\title{
Impact of Accounting Ethics on the Practice of Accounting Profession In Nigeria.
}

\author{
${ }^{1}$ Akadakpo, Bukola A. (Mrs), ${ }^{2}$ Enofe, Augustine O. \\ ${ }^{I}$ Department of Accounting, Faculty of Management Sciences, University of Benin, Benin City. Nigeria.
}

\begin{abstract}
This study is an empirical investigation of the impact of ethical values on the practice of accounting profession in Nigeria. To achieve the purpose of this study, research questions were raised, hypotheses were formulated, and a review of related literature was made. The main objective of this study is to examine if accounting ethics have much impact on the practice of accounting profession in Nigeria, the factors that make the accountants breach accounting rules and if ethical codes of conduct address all the issues that border on ethical practices. The study employed a synthesis of descriptive and survey research methods. The major instrument used for generating the primary data was the questionnaire, which was designed in five-response option of likert-scale. Two hundred and fifty (250) questionnaires were administered, two hundred and nineteen (219) questionnaires were completed and returned. The data generated for this study were analysed through mean scores while the stated hypotheses were statistically tested with z-test. Our findings revealed that there are other major influence which accountants believe have impact on their professional conducts like policies and rules of companies where accountants work, religion were found not to have major influence in the professional conduct of accountants. The legal system and societal value systems also inter-played in the accountants' professional conduct. It was recommended among others that the accountant in practice needs to pay attention to good ethical conduct and there is the need to adhere strictly to the ethical code of conduct.

Keywords: accounting profession, accounting ethics, ethical codes of conduct, Nigeria.
\end{abstract}

\section{Introduction}

There are a number of situations in which the guidelines or ethical codes appear not too relevant. In such situations, accountants attempt to resolve such issues by chosing from their actions. Many accountants are likely to resolve conflict of interest, situation that border on loss of revenue or job, personal interest and beliefs cultural background and double standards in the application of sanctions without reference to the expectations of the accountancy profession (Akadakpo and Izedonmi, 2013). The issue of what is wrong or right comes up on a daily basis and the practicing accountant, students of accounting, preparer of accounts, accountants planning to set up professional practice, as well as accountants not in practice have obligation to conduct themselves within the limits of good ethical standards.

A well-run profession or business must have high and consistent standards of ethics in order to stand fast and to stand the test of time (Smith and Smith, 2003). Finance and accounting departments in industries are taking ethical considerations to be extremely important (Vickers, 2005 as cited in Mathenge, 2012). A tension often exists between a company's financial goals and strategies to improve profits, and ethical considerations with concerns for right-behavior. When the public loses confidence in the ability of the market to prevent corporate misbehavior, it often demands increased government regulation. For example, frequent cases of misconduct by corporate executives have led to the passage of various Acts in Nigeria, Such Acts include the Companies and Allied Matters Act, 2004 Cap C20, LFN, the Economic and Financial Crimes Commission (EFCC) Act, 2004, the Investment and Securities Act (ISA) 2007, the Independent Corrupt Practices and other Related Offences (ICPC) Act 2003, Banks and other Financial Institutions Decree 2004, the Nigerian Deposit Insurance Corporation Act 2006, Money Laundering Act, and many others.

The ethical lapses among public accountants, these has necessitated a revision of the accounting professional standards (Rist, 2002). Interestingly, professional accountant working in accounting firms are faced with new challenges within the profession as a result of the debacles of large corporations (Swift, 2002). Organizational cultures and environment pose a good opportunity for accountants to exploit the loopholes in reporting and financial management. Though finance and accounting departments in most organisation are expected to foster the growth of ethical education and awareness but they are often faced with stiff resistance from the top level management (Fisher and Lovell, 2009).

Ethical standards set by professional accounting bodies in Nigeria, ICAN and ANAN, can act to supercharge the engine of morality and good conducts in the discharge of auditing functions in Nigeria. Efforts are being made to introduce and enforce the practice of ethical standards by the regulatory bodies, however, strict adherence to the standards has been a problem (Gowthorpe and Amat, 2005). 


\subsection{Statement Of Research Questions}

Even though recognized professional accounting bodies in Nigeria, like ICAN and ANAN, are trying very hard to ensure best practice in the auditing profession via the enforcement of professional code of conduct for their members, the strict observance of such codes is still questionable. This study examine the need for good ethical values in professional practice of public accounting in Nigeria. Since there is growing critism of accountants in public practice and their counterparts in private sectors then it is of significance to embark on a study such as this to further explore the relationship between accounting ethics and the practice of accounting profession in Nigeria. The following research questions were raised to address this problem.

1. Does ethic have much impact on the practice of accounting profession in Nigeria?

2. Does ethical codes of conduct address all the issues that border on ethical practices?

\subsection{Objectives of The Study}

The objectives of this study are to find out:

1. Whether accounting ethics have any impact on the practice of accounting profession in Nigeria.

2. Whether ethical codes of conduct address all the issues that border on ethical practices.

\subsection{Research Hypothesis}

\section{Hypothesis I}

Hypothesis II

The professional ethical code of conduct is not sufficient to guide accounting practice in Nigeria.

Ethics does not have much impact on the practice of accountancy profession in Nigeria.

\subsection{Scope of Study}

The scope of the study is practicing accountancy firms as well as chartered accountants in business, higher educational institution, non government parastatal, vocation and trade in some selected state in Nigeria (Benin City, Auchi, Lagos, Asaba, Bayelsa, Warri and Abuja).

\subsection{Conceptual Framework}

\section{Literature Review}

The main drive of accounting ethics and ethical values is the upholding of professionalism and good practice. Perhaps, we start an exploration of the subject ethics by looking at some of the meaning. Ethical responsibility in the business world according to Micewski and Troy (2006) is not holistic, but what we can do is consider any phenomenon that within a certain context influences ethical behavior. In most corporations in the world, the largest ethical issue in the accounting process is the potential for conflict of interest (Gomez, 2002). The breach of ethical rules in the practice of corporate financial reporting is not fair to users and such action can jeopardize the main objective of the financial reports (Gowthorpe and Amat , 2005).

Brinkmann (2002), defined ethics as a discipline in which matter of right and wrong, good and evil, virtue and vice are methodically examined. Ethics looks at human behavior, moral principles and the attempt to distinguish good from bad. When trying to identify common issues being dealt with within the business environment, professional bodies' codes of ethics is the right place to look. These codes represent what we can consider to be the reflection of business ethics. Codes of ethics should mainly address the particularities of high risk activities and are built on the collective conscience of a profession as a proof for the group's acknowledgment of the moral dimension.

According to Smith and Smith (2003), ethical values provide the foundation on which a civilized society exists. Nowadays, ethical standards act as a compass that direct and monitor the actions of people so that the best true and fair practices are achieved. Doolan (2009), append that assuming a person derives ethical values from religious principle, history and literature, or personal observation and experience, there are some basic ethical guidelines and ethical codes to which everyone can agree.

In the particular case of the accounting profession we should mention the International Federation of Accountants' (IFAC) code of ethics establishing the standards for accounting professionals behavior and displaying the fundamental principles they should respect in order to fulfill their common objectives. IFAC's code of ethics generally adopts a principles-based approach. The five fundamental principles in the IFAC code are: integrity; objectivity; professional competence and due care; confidentiality; and professional behavior (IFAC, 2006).

\subsection{A Review of Relevant Literature in Nigeria}

Akadakpo and Izedonmi (2013), opined that most regularly breaches codes are those that border on independence, integrity, transparency and objectivity. Members (Institute of Chartered Accountant of Nigeria, 
ICAN or Association of National Accountant of Nigeria, ANAN) accept jobs without professional clearance from previous auditors/consultants. Some members also breaches accounting ethic codes, such as wrong and false reporting of financial information, embezzlement, fraud and corrupt practices, non-disclosure of conflict of interest and collecting and giving out gifts to influence judgement.

Ogbonna and Ebimobowei (2012), evaluated the effect of ethical accounting standards on the quality of financial reports of banks in Nigeria, and they came to the conclusion that the analysis of the data showed that ethical accounting standards affect the quality of financial reports of banks in Nigeria.

Adeyemi and Fagbemi (2011), concluded that there is the need for the profession to direct its efforts towards shaping the views of new entrants to the profession. This can be achieved through sound ethical training as results from the study suggested that this is an important step towards restoring the integrity of financial reporting process. Adherence and enforcement of high ethical standard for members of the profession will go a long way in maintaining diligence in the way members of the profession carry out their duties.

Ajibolade (2008), in the study "a survey of the perception of ethical behaviour of future Nigerian accounting professionals", indicated that future professional accountants should be properly groomed in ethical standards which is normal for professional growth and improvement of services delivery in financial reporting and auditing in order to maintain the respectability of the profession.

Bakre (2007) is of the view that accountants, auditors, and the accounting professional bodies in Nigeria for extremely poor level of integrity observed. The study also revealed that there were no significant differences in the perceptions of respondent groups on the need for auditors to abide by high ethical standard and the need to shape the views of new entrants to the profession.

\section{Methodology}

This study was conducted to examine the impact of ethnics on the practice of Accountancy Profession in Nigeria. While conducting this research, data were collected primarily from questionnaire and oral interviews. The analysis and interpretations and findings from this work are strictly based on the information obtained from selected practicing chartered accountants in Nigeria. The population for this study includes chartered accountants in Nigeria.

A sample size of 250 chartered accountants in public practice, government, trade, vocation and academics was used. The data collection is the questionnaire.

The questions are structured types. The responses are mostly of the multiple-choice types. The questionnaire is broadly categorized into two sections. the first section contains questions relating to the background of the respondents which is the type of organization worked for, sex and years of experience. The second section relates to ethical procedures and practices which seek to find out the respondents knowledge of ethical issues and how they have been dealing with it in their everyday practice. The hypotheses formulated were tested using data generated from the fieldwork. The Z-score test was used in testing the hypotheses at 5\% level of significance under the two-tailed test.

\subsection{Questionnaire Analysis}

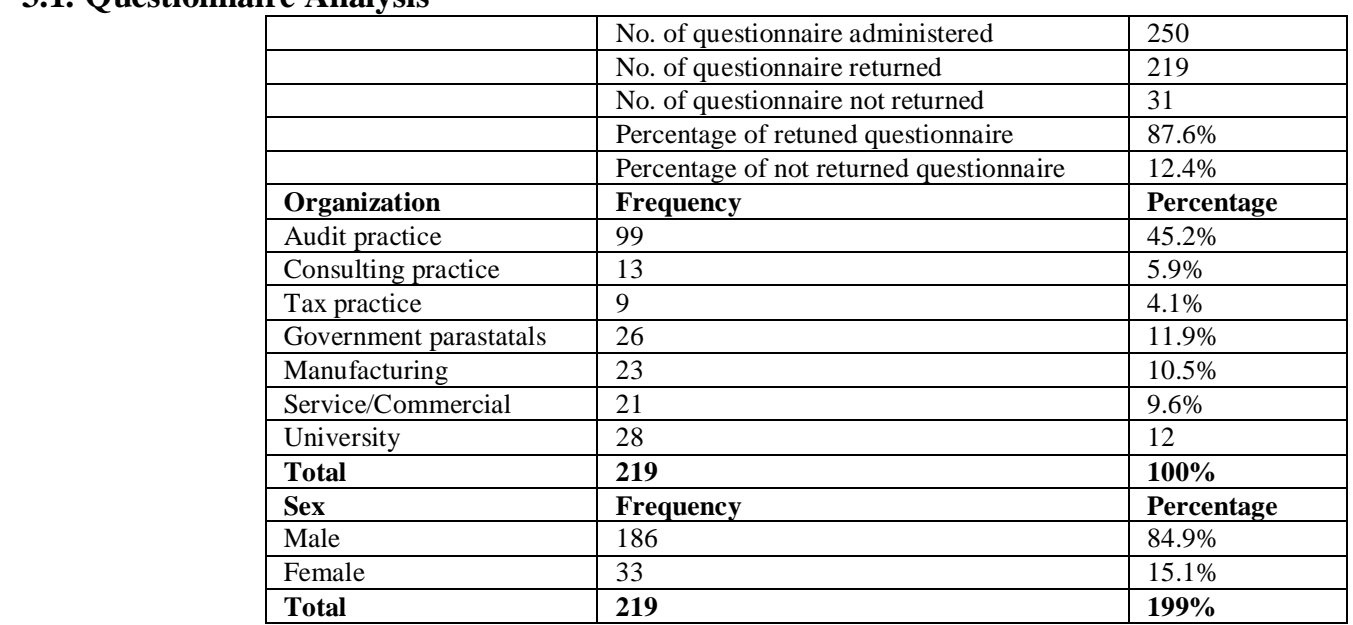

\section{Source: From questionnaire administered}

From the table above, two hundred and fifty questionnaires were administered, two hundred and nineteen questionnaires were completed and returned which constitute $87.6 \%$ of the questionnaire. Thirty-one representing $12.4 \%$ of the questionnaires were not returned. This mean that $87.6 \%$ of the questionnaire was a success while $12.4 \%$ was failure. Respondents from audit practice constituted the bulk (45\%) of the sample, 
consulting practice constituted $5.9 \%$ of the sample, tax practice $(4.1 \%)$ of the sample, government parastatals $(11.9 \%)$ of the sample, manufacturing, service/commercial and University constituted $10.5 \%, 9.6 \%$ and $12.8 \%$ of the sample respectively. $186(84.9 \%)$ respondents were males while the balance of $33(15 \%)$ were female.

Table 4 Major influence in respondents professional practice (Q1)

\section{Source: From questionnaire administered}

\begin{tabular}{|l|l|l|}
\hline Opinions & Frequency & Percentage \\
\hline The professional ethnical codes & 84 & $38.4 \%$ \\
\hline The Nigeria legal system & 24 & $11 \%$ \\
\hline My religion & 47 & $21.5 \%$ \\
\hline Imbibed societal value system & 9 & $4.1 \%$ \\
\hline My belief in not harming the society & 12 & $5.5 \%$ \\
\hline My company's policies and rules & 43 & $19.6 \%$ \\
\hline Total & 219 & $100 \%$ \\
\hline
\end{tabular}

Table 4 above clearly shows that the accountancy professional ethical codes have the strongest influence on the conduct of accountants in their professional practice as $38.4 \%$ of the sample attributed their professional conduct to this factor. Religion was also found to be a major influence in the professional conduct off accountants with $21.5 \%$ of the sample. The policies and rules in the companies in which accountants work have a strong influence on their conduct, this constituted $19.6 \%$ of the sample. Other important influences are the Nigeria legal system (11\%) societal value system (4.1\%) and respondents' belief is not harming the society $(5.5 \%)$ of the sample.

Table 5 Regularity of updating accountants with ethical codes (Q2)

\section{Source: From questionnaire administered}

\begin{tabular}{|l|l|l|}
\hline Opinions & Frequency & Percentage \\
\hline Every six months & 49 & 22.4 \\
\hline Once every year & 85 & 38.8 \\
\hline Once every two years & 54 & 24.7 \\
\hline Once every three years & 14 & $6.4 \%$ \\
\hline Less often & 9 & 4.1 \\
\hline Cannot say & 8 & 3.7 \\
\hline Total & 219 & $100 \%$ \\
\hline
\end{tabular}

From the table above, $38 \%$ of the respondents expressed the opinion that professional accountants should be reminded or updated with the accountancy ethnical standards once every year. About a quarter $(24.7 \%)$ of the respondents were of the opinion that every two years will suffice while $22.4 \%$ of the respondents want to be updated every six months. Whole some respondents $(6.4 \%)$ want to be updated once every three years, $4.1 \%$ of the respondents want to be updated less often while $3.7 \%$ of the respondents cannot really say.

Table 6 Importance of signing declaration of compliance with ethical code (Q3)

\begin{tabular}{|l|l|l|}
\hline Opinions & Frequency & Percentage \\
\hline Very important & 121 & $55.3 \%$ \\
\hline Just important & 52 & $23.7 \%$ \\
\hline Neither important nor unimportant & 21 & $9.6 \%$ \\
\hline Unimportant & 11 & $5.0 \%$ \\
\hline Very unimportant & 6 & $2.7 \%$ \\
\hline Do not know & 8 & $3.7 \%$ \\
\hline Total & 219 & $100 \%$ \\
\hline
\end{tabular}

\section{Source: From questionnaire administered}

Table 6 above shows that most respondents (55.3\%) expressed the opinion that signing declaration of compliance with ethical code as very important while $5.0 \%$ of the respondent were of the that signing declaration of compliance with ethical codes as unimportant, while $9.6 \%$ of the respondents are indifferent about signing declaration of compliance with ethical code.

Table 10 Regularity with which respondents were faced with situation that border on conflict of interest

\begin{tabular}{|l|l|l|}
\multicolumn{2}{l}{$(\mathbf{Q 7 )}$} \\
\hline Opinions & Frequency & Percentage \\
\hline Very often & 23 & $10.5 \%$ \\
\hline Just often & 51 & $23.3 \%$ \\
\hline Neither/indifferent & 11 & $5.0 \%$ \\
\hline Not often & 122 & $55.7 \%$ \\
\hline Never & 5 & $2.3 \%$ \\
\hline Don't know & 7 & $3.2 \%$ \\
\hline Total & 219 & $100 \%$ \\
\hline
\end{tabular}




\section{Source: From questionnaire administered}

Table 10 above shows that $55.7 \%$ of the respondents claimed that they are not often faced with situations that at one time or other border on conflict of interest that can make them breach ethical standards $23.3 \%$ of the respondents saw such situations as just often. $10.5 \%$ of the respondents claimed to have faced such situation very often. While $5 \%$ of the respondents were indifferent to the situation.

Table 11 Specific Areas in which Respondents often face conflict of interest. (Q8).

\begin{tabular}{|l|l|l|}
\hline Opinions & Frequency & Percentage \\
\hline Presentation of report/Reporting Financial information & 29 & $13.2 \%$ \\
\hline Tax matters/compliance with technical standards & 18 & $8.2 \%$ \\
\hline Honesty, integrity, probity, objectivity and independence & 13 & $5.9 \%$ \\
\hline Giving or Receiving gratification & 8 & $3.7 \%$ \\
\hline Audit & 16 & $7.3 \%$ \\
\hline None & 27 & $12.3 \%$ \\
\hline Don't know/ can't say & 108 & $49.3 \%$ \\
\hline Total & 219 & $100 \%$ \\
\hline
\end{tabular}

\section{Source: From questionnaire administered.}

From table 11 above, respondents were asked the specific areas of their practice in which they often face conflict of interest that border on ethical standards, almost half of the respondents claimed not to have any idea $13.2 \%$ of the respondents said in presentation of report or reporting financial information. $12.3 \%$ of the respondents said there are no areas. $8.2 \%$ of the respondents claimed in tax matters/compliance with technical standards, $7.3 \%$ of the respondents claimed in audit, $5.9 \%$ of the respondents claimed their honesty, integrity, probity, objectivity and independence. While $3.7 \%$ of the respondents claimed in giving or receiving gratification.

Table 12 How respondents resolve conflict of interest (Q9)

\begin{tabular}{|l|l|l|}
\hline Opinions & Frequency & Percentage \\
\hline Contact my superior for advice & 51 & $23.3 \%$ \\
\hline Contact my colleagues for advice & 35 & $16.0 \%$ \\
\hline Take a position based on my personal beliefs or interest & 26 & $11.9 \%$ \\
\hline Abide by the ethical standards of the accounting profession & 73 & $33.3 \%$ \\
\hline Take a position that will be more beneficial to my organization & 18 & $8.2 \%$ \\
\hline Don't know/can't say & 16 & $7.3 \%$ \\
\hline Total & 219 & $100 \%$ \\
\hline
\end{tabular}

\section{Source: From questionnaire administered}

From the analysis above, $33.3 \%$ of the sample interviewed claimed they would resolve conflict of interest by abiding by the ethical standards of the accounting profession $23.3 \%$ of the respondents will contact their superior for advice, $16.0 \%$ of the respondents will contact their colleagues for advice while $11.9 \%$ of respondents will take a position based on their personal beliefs or interest and $8.2 \%$ of the respondents will take a position that will be more beneficial to their organization.

\subsection{Test of Hypotheses and Analysis of Results}

\section{Hypothesis 1}

The professional ethical code of conduct is not sufficient to guide accounting practice in Nigeria In testing hypothesis 1 , question 13 was used.

Table 16: Analysis of responses to question 13

\section{Source: Fieldwork (2010)}

\begin{tabular}{|l|l|l|}
\hline Opinions & Frequency & Percentage \\
\hline Strongly agree & 68 & $31.1 \%$ \\
\hline Moderately agree & 59 & $27.0 \%$ \\
\hline Indifferent & 27 & $12.3 \%$ \\
\hline Disagree & 29 & $13.2 \%$ \\
\hline Strongly disagree & 36 & $16.4 \%$ \\
\hline Total & 219 & $100 \%$ \\
\hline
\end{tabular}

\section{Decision Rule}

The empirical analysis shows that the table Z-value of 1.96 is greater than the calculated Z-value of 2.66. In the figure above the calculated $\mathrm{Z}$-value falls outside the acceptance region into the rejection region which means that we reject the null hypothesis and accept the alternative hypothesis which states the professional ethical code of conduct is not sufficient to guide accounting practice in Nigeria. 


\section{Hypothesis 2}

Ethics does not have much impact on the practice of accountancy in Nigeria. In testing hypothesis 2, question 15 was used.

Table 18: Analysis of responses to question 15

\begin{tabular}{|l|l|l|}
\hline Opinions & Frequency & Percentage \\
\hline Strongly agree & 88 & $40.2 \%$ \\
\hline Moderately agree & 62 & $28.3 \%$ \\
\hline Indifferent & 19 & 8.7 \\
\hline Disagree & 27 & $12.3 \%$ \\
\hline Strongly disagree & 23 & $10.5 \%$ \\
\hline Total & 219 & $100 \%$ \\
\hline
\end{tabular}

Source: Fieldwork (2010)

\section{Decision Rule}

The empirical analysis shows that the table Z-value of 1.96 is greater than the calculated Z-value of 6.9. In the figure above the calculated $Z$-value falls outside the acceptance region into the rejection region which means that we reject the null hypothesis and accept the alternative hypothesis which states that ethics does not have much impact on the practice of accountancy in Nigeria.

\section{Conclusion And Recommendations}

Ethical codes of the accounting profession have a strong influence on the conduct of accountants. It was found that there are other major influence which accountants believe have impact on their professional conducts like policies and rules of companies where accountants work, religion were found not to have major influence in the profession conduct of accountants. The legal system, societal value systems and beliefs in not harming the society also inter-played in the accountants' professional conduct.

Many accountants are of the opinion that the ethical codes by the professional bodies in Nigeria, ICAN and ANAN is insufficient in their profession conduct as they confirm that other factors have an inter-play in their day to day professional conduct. Certain situation such as giving out gratification, working in an organization that produces products that may be injurious to human health and exerting high pressure in securing professional jobs may not be regarded as too ethical but in which ICAN does not enforce sanction because the ethical codes do not cover such situations. In addition, technological development has extended the horizon of information flow which is available to accountants in their everyday practice. But the confidentiality and integrity of such information cannot be fully relied upon. The accountant is at risk of publishing such information and may expose himself to litigation if such information is subsequently found to be incorrect. The ethical codes do not cover such cross border information and thus extend the liability of accountants.

Based on the findings generated from this study the following recommendations are made:

1. The accountant in practice needs to pay attention to good ethical conduct and there is the need to adhere strictly to the ethical code of conduct.

2. Members need to sign a declaration of compliance with ethical codes periodically. This may be once every year or two years.

3. ICAN needs to wait till a case is formally reported but may cause preliminary investigation to be commenced once the general public becomes aware of such breach. This may be through the new mediaprinted or electronic.

4. The most breached offences need to continue to attract the most sanction.

\section{References}

[1]. Adeyemi, S. B., \& Fagbemi, T.O. (2011). The perception of ethics in auditing profession in Nigeria. Journal of Accounting and Taxation. 5(7), 146-157.

[2]. Ajibolade, S. O. (2008). A survey of the perception of ethical behaviour of future Nigerian accounting professionals. The Nigerian Accountant. 43(3), 54-59.

[3]. Akadakpo, B.A., \& Izedonmi, O.I.F. (2013). Ethical Practices of the Professional Accountant in Nigeria. Research Journal of Finance and Accounting. 4(7), 59-66.

[4]. Bakre, O. M. (2007). The unethical practices of accountants and auditors and the compromising stance of professional bodies in the corporate world: evidence from Nigeria. Accounting Forum, 31, 277-303.

[5]. Brinkmann, J. (2002). Marketing ethics as professional ethics: concepts, approaches and typologies. Journal of Business Ethics, 41(1/2), 159-177.

[6]. Doolan, A. L. (2009). Ethical issues in accounting: A teaching guide. 2009 ABR \& TLC Conference Proceedings, Oahu, Hawaii, USA.

[7]. Fisher, C., \& Lovell, A., (2009). Business Ethics and values: Individual, Corporate and International Perspectives, (3rd ed.). Edinburgh Gate, England: Pearson Education Ltd.

[8]. Gomez, R. (1999). A Primer on Business Ethics: What's Right and Wrong in Business?, (2 ${ }^{\text {nd }}$ ed.). Manilla, Sinagtala Publishers.

[9]. Gowthorpe, C., \& Amat, O. (2005). Creative accounting: some ethical issues of macro- and micro-manipulation. Business Ethics 57, 55-64. 
[10]. International Federation of Accountants (IFAC), (2006). Approaches to the Development and Maintenance of Professional Values, Ethics and Attitudes in Accounting Education Programs. Information Paper. New York. Retrieved from http://www.ifac.org.

[11]. Mathenge, G. D.(2012). Ethical dimensions in responsible professionalism and accounting procedures in Kenya: A critical analysis of theory and practice. Research Journal of Finance and Accounting, 3( 2), 58.

[12]. Micewski, E. R., \& Troy, C. (2006). Business ethics - deontologicaly revisited. Journal of Business Ethics. 72 (1), 17-25.

[13]. Ogbonna, G.O.,\& Ebimobowei, A. (2012). Effect of ethical accounting standards on the quality of financial reports of banks in Nigeria, Current Research Journal of Social Sciences. 4(1), 69-78.

[14]. Rist, J. M., (2002). Real Ethics, Reconsidering the Foundations of Morality. Cambridge: Cambridge University Press.

[15]. Smith, K. T. and Smith, L. M. (2003). Business and Accounting Ethics. T \& M University: Texas.

[16]. Swift, T., (2002). Trust, reputation and corporate accountability to stakeholders. Business Ethics: An European Review 10(1):16-26

[17]. The Institute of Chartered Accountants of Nigeria (2000). Rules of Professional Conduct for Members. The Institute of Chartered Accountants of Nigeria: Lagos.

\section{APPENDIX}

\section{Z-Test: One Sample for Means}

Mean

Known Variance

Observations

Hypothesized Mean Difference

Z

$\mathrm{P}(\mathrm{Z}<=\mathrm{z})$ one-tail

$\mathrm{z}$ Critical one-tail

$\mathrm{P}(\mathrm{Z}<=\mathrm{z})$ two-tail

z Critical two-tail

\section{Z-Test: One Sample for Means}

Mean

Known Variance

Observations

Hypothesized Mean Difference

$\mathrm{Z}$

$\mathrm{P}(\mathrm{Z}<=\mathrm{z})$ one-tail

z Critical one-tail

$\mathrm{P}(\mathrm{Z}<=\mathrm{z})$ two-tail

z Critical two-tail

Source: SPSS OUTPUT
Variable 1

43.8

2.15

219

0

2.667569588

0.116518991

1.644853627

0.233037982

1.959963985

\section{Source: SPSS OUTPUT}

Variable 1 43.8

3.69

219

0

6. 96675588

0.116518991

1.644853627

0.233037982

1.959963985 